\title{
Knowing other-wise: a discussion of alterity and the limits of philosophy
}

\author{
Hendrik Hart \\ Institute for Christian Studies \\ Toronto, Ontario \\ CANADA
}

\begin{abstract}
Hendrik Stoker and Herman Dooyeweerd discussed the relation between philosophy's universality and the independence of the individually real. That issue is currently discussed by posimodern philosophers exploring the limits of philosophy related to contemporary concern for inclusivity and alterity. I take up this issue by arguing that philosophy has limits. If these are not observed, philosophy contributes to exclusion or oppression of whatever transcends these limits. If, for example, philosophy imperiously sets the tone for our total relation to the real, its limits shrink our relation to the real. For if philosophy is limiled by a focus on what is same, such imperious tonesetting will exclude the different from our attention. Calling attention to the inclusion and liberation of 'differents' is a contribution of postmodernity. But I ask: can such calling attention remain philosophical without philosophy remaining imperial? Possibly our knowing of the different must be a knowing that differs from knowing the same. In my view, knowing what is 'otherwise than being', is knowing otherwise than knowing philosophically. Such knowing will be othenwise by being wise to the other, in trust. It will not be a grasping of the other in and by a concept that is the same.
\end{abstract}

\section{Preface}

Hendrik Stoker's concern that philosophy be inclusive was especially evident in his discussions with Herman Dooyeweerd, both orally and in writing, spread over some thirty years from the early thirties to the mid-sixties. Stoker's contributions to these discussions occur especially in the last two essays of Oorsprong en rigting 2 (1970: 202-410). For Dooyeweerd the most important places to consult are in A New Critique of Theoretical Thought (1953:94-107 vol. 1 and 1957:6176 vol. 3).

Stoker did not want to neglect or exclude any aspect of created reality, no matter how seemingly insignificant. He was concerned, for example, that Dooyeweerd 
did not do justice to the actual and concrete reality of events or to the peculiar particularity of individuals. To give expression to his concern Stoker proposed not only the cosmic dimension of events, but also the category of the 'idion,' the irreducible reality of something creaturely 'in its own right', or, as he expressed it, its "eie-standigheid". Stoker feared that Dooyeweerd's thought obliterated some dimensions of creation with his pervasive and encompassing view of creation's law side. He wanted to stress that all creatures have an inviolable, irreducible right to a difference of their own being.

Dooyeweerd maintained, however, that Stoker's concerns threatened to neglect the creature's total dependence on the law of God, as well as that these concerns should not lead to philosophy's dealing with everything whatsoever. Philosophy has its limits. And some of Stoker's concerns, real though they were, transcended the proper limits of philosophy in Dooyeweerd's view.

I have always sympathised with both men. I agreed with Dooyeweerd that philosophy has its limits and that Stoker seemed too eager not merely to do justice to all reality, but to do so philosophically. But I also heard in Stoker's objections an intuition that in Dooyeweerd's philosophy little space was left in the universc for the reality of creation beyond its law side.

At that time it would have been impossible to articulate what today might be called a 'postmodern' intuition in Stoker: a respect for inclusivity and alterity that was absent in traditional philosophy. In Dooyeweerd such 'postmodern' intuitions were arguably present as well, though not in the area of Stoker's concerns Dooyeweerd's are found more in his analysis of the autonomy of reason. Stoker was out to include the individual in its own individuality. However, his conceptualization or thematization of his 'inclusivity intuition' may have been partly to blame for a troubling inconsistency, which only now, given our postmodern as well as our approaching post-apartheid context, becomes clear to us. This inconsistency comes to the surface in his desire to include the different within the philosophical arena of the same, which may have left him blind to apartheid as a reality of exclusion. It is possible that the only inclusion of the black other he could muster was within a white intellectual system which in the reality of practice oppressed and excluded that black other Possibly Stoker's intuitions about alterity remained so imprisoned within a conceptual system, in spite of his intentions, that the real other, in his case the black other, escaped his full attention. Possibly, though Stoker's intuition about Dooyeweerd was right, Dooyeweerd was also right to say that a more inclusive philosophy would not be the way to deal with the problem.

May room for an other, conceptually enclosed in a theoretical view, perhaps make it difficult to keep sight of the actual other? Is it possible that justice for an other confined to a conceptual system results, not in a genuine plurality of people, 
but rather in others reduced to otherness, while real others are kept 'out' or apart? To honour Stoker in the centemial year of Dooyeweerd's birth, I take up the issue they raised once again, though not by revisiting their discussion. Rather, $I$ address the issue in its postmodern form. But I also treat it within the framework of the tradition in which Stoker and Dooyeweerd worked, namely that of reformational philosophy. I want to explore the limits of philosophy in relation to our concern for alterity, by placing philosophy in relation to the philosophizing self. It will then appear that concern for an other which remains a philosophical concern, may be limited to a concern for an other who is self-same. A merely philosophical concern for alterity thus may keep a truly other self apart from the world of same selves. On the other hand, a concern for an other which includes that other in my own world, may require an awareness of that world beyond the limits of philosophy, a being present in the world beyond the limits of being as presence.

\section{The typical Western Ego}

Western self-identity at its core has strong traditional connections with self as being, a self whose being is being rational. Examples are Descartes' cogito, Kant's transcendental-logical ego, and the popular self-definition of 'man' as rational animal. The note of triumph in cogito ergo sum is the certainty of being: 'Therefore $I \mathrm{am}^{\prime}$ '. It is a triumph rooted in its being established rationally: cogito! ergo. So there! Self-assured reassurance of being self.

This Western self, for all practical purposes as well as essentially, is a privileged white, heterosexual, and powerful male in whose own life as thinking subject other human functions such as trust, feeling, sensation, emotion, being body, and others are thought less of. A self who 'de-fines' himself as rational self, surrounds himself by or encloses himself within rational boundaries: the 'fines ' within which he is self. That excludes these other functions from his proper self, even if he cannot deny they are his. Further, this rational self, in a manner of speaking, also 'excludes' or sees as outside the rational enclosure within which he is being himself, 'other' selves who are not same selves. That is, he excomınunicates from proper humanity, to one degree or other, women, poets and painters as truthmakers, homosexuals, Jews, the poor, people of colour, and others (Lloyd 1984; Nye, 1990).

The rational self, reason, also sees whatever is other than the sameness in whose guise all things appear to this self, as outside of the enclosure of proper being. So he depreciates difference, transcendence, subjectivity, individuality, spirituality, feeling, and more. The real world of this rational-world-making-self is thus a reduced world. Like the self that project-ed it and thus $o b$-ject-ified it, it is a world of being, whose being is its being immutably rational, cast in the mould 
of reason by being held out before it in a fixed gaze, then cast out. Rational being is true, essential, real being. The rest of what there is, is a reality manqué, $i s-n o t$, has no being, is called $m \dot{e}$ on by Parmenides. His stage-setting demarcation of thinking, being, and sameness still has most of philosophy in its grip. Postmodern divided selves may be divided precisely because of their reluctance to really let go totally of the totalizing grip of rational sameness.

\section{Initial observations about philosophy's role in the world of reason}

To put his life 'in order' the rational self, also known as reason, autonomously develops a rational tradition known as philosophy: the story of the thinking self who in philosophy orders or structures being in its immutable universality, totality, and self-identity; being as present to thought. The word of philosophy, in this tradition, is a first and last word. Philosophy, or reason in philosophy, makes sense of "it all" (Bruggemann-Kruyff, 1993).

Philosophy in this philosophical tradition - in its disciplines, important figures, and movements - has mainly two different, though related versions: philosophy as rational theory of the most general order or structure of what, generally speaking, there is or is there (for example ontology, metaphysics, Kant, Husserl, analytic philosophy) and philosophy as practical wisdom (for example moral philosophy, philosophy of culture, Pascal, Kierkegaard, pragmatism). Sometimes the two traditions come together (Heidegger). In both versions philosophy is the rational product of a rational self, a reasoned body of thought with universal validity, known as truth. This remains true even where we see a struggle between the priority of being empirical and the legitimacy of being speculative, for example between Lockeans and Cartesians; misleadingly identified as empiricists and rationalists. For the empiricists, too, were rationalists (Schouls, 1980).

There is, of course, nothing wrong with thinking rationally about the ultimate issues of human life, whether in structure-theoretical terms or in terms of practical wisdom. It has been helpful, for example, that in developing the philosophical tradition we rationally discovered certain dangers to human existence. The Enlightenment discovered such dangers in blind faith, absolute authority, and superstition and marked these as unreasonable. Nevertheless, the 'overall rational' view of general structure and the contributions it makes are one thing, 'ultimate orientation' in matters of human destiny construed rationally is another. A rationally developed philosophical tradition genuinely contributes to putting our life in order by providing the broadest possible account, within the logical space of reasons, of how things broadly construed hang together in the broadest possible sense. Many readers of Richard Rorty do not notice that in most of his works this view of philosophy is unproblematically acceptable to him. However, 
when reason replaces myth and spirituality, when it disçualifies our coping with the mystery of life we encounter beyond the bounds of reason, when it denies that there are such bounds, does it then make a similar contribution? That is, if we assign to reason what was once done in faith (trust, not belief) on the ground that trust is necessarily blind, that its authority is absolute per se, and that its revelation is not reasonable, might that not amount to a closure of first order sources of authentic wisdom?

A question thus arises: is it possible to develop a rational, universal, empirical account of the eschatological, mystery laden, mythically articulated spirituality of the human jounney between origin and destiny? Could it be that logo-power as first-last word, rational plitosophy as path of wisdom, reason as comprehensive control of reality via sameness, presence, and generality, mis-'leads' us when we do not acknowledge this as reason taking on roles that are not as such rational? Are these not roles that develop within reason only if we trust reason as last word? And is that consistent with trust's having been banned from the life of reason in this philosophical tradition?

The vicw of reason and philosophy as capable of chcompassing reality or of reality as contained within the bounds of reason; that is, the view of reason in which $/ t$ is the limit of all things while it is itself mulimited, that view is likely related to, among others, the nature of intellectual com-prehension of sameness as well as to the intellectual aim for universality, neither of which is necessarily improper. By aiming for a complete, full, total 'grasp' of all propertics and relations which we concerve as common to 'all' things of some kind, we seem to conceive it com-prehensively. Reason, especially in philosophical thought, thus thinks totality, thinks it grasps totality in a single, universal, true image. The rational, theoretical, philosophical picture of the Western tradition, however, can be seen as blowing this all up, as enlarging the philosophical picture without seeing that the world which fits within that picture has been fragmented. Intellectual grasp) or conceptualization is taken as not just an idealized focus on one side of reality (Lakoff, 1987), but as grasp of the whole truth, as grasp of what encompasses all reality, as having hold of the controlling limits or boundaries of the real.

With the rise of this aspiration, reason desires to replace faith, religion, and fundamental trust. But it may well not be ridding itsclf of trust and authority. lnstead, it may foster a new, though hidden, form of trust in a new absolute authority, namcly unconditional trust in the authority of reason. Philosophy, in this new guise, offers itself as our guide with the problems of life, to help us see who we are or may become. Ihilosopliy, that is, replaces traditional religion by becoming the new religion of the high priesthood of the intellectual generalist. But is philosophy then still rational/theoretical? Is the rational self who follows 
reason as the sure path to the promised land, as our prime hope for human happiness, is that self in so doing still doing something rational?

\section{Initial demarcation of some problems}

Both feminist philosophers and postmodern thinkers have helped us become aware of problems in a philosophical tradition which is logocentric, that is, which not only orients itself as an intellectual tradition to being rational, but which also puts reason at the centre of self, humanity, and the rest of reality. The then unavoidable rational reduction of whatever is real to its 'being', its sameness to reason, results in equally unavoidable marginalization of whatever is different: denial of what transcends reason, erasure of the other, oppression of what will not be so denied or erased (Code, 199l). Aristotle already struggled with these consequences of our life's orientation to reason, by indicating task divisions within the life of reason between episteme and phronesis and between theoretical philosophy and practical philosophy. I see in that struggle an acknowledgement of certain limitations within reason on the one hand, while on the other hand an attempt is made to have reason remain universally totalizing nevertheless. Kant's work on practical, theoretical, and aesthetic reason has similar characteristics. There is an intuitive awareness that rational philosophy is, on the one hand, constitutionally incapable of real totality, while on the other hand it seems as though the totality of being remains within reason's control. So if our life is to be put in order philosophically, both theoretically and practically, by a tradition of reason which itself is limited and is not the limit of the real, then what if reason forgets those limits? Then subjectivity, individuality, and difference will not be able to find a place of honour within the tradition, will be marginalized. The order of a life thus put in order will be reduced to an order of sameness, a sameness concentrated in a desire for power and control.

In our very day we see a continuation of this struggle in the work of people who have been impressed with the postmodern and feminist critique of reason, but who struggle with taking their leave of an essentially rational self which hangs on to an autonomous last word. Their solution seems to be the traditional one: building more of what has to remain outside of reason into reason itself. Then philosophy can continue to excercise its power, but more inclusively. I raise the question, however, whether we can expect any real healing from a rational philosophy tradition whose marginalization is unavoidable by the very fact of its being rational. Is a more inclusive philosophy likely, in which an exclusionary interest, reason, still is autonomous and has the first/ last word? Philosophy has limits, margins. Including all things within those limits will marginalize what does not fit. If philosophy is rational and reason's focus on the same requires exclusion of the different, how then can philosophy as philosophy ever be truly universal in the sense of doing justice to the real different? Is it realistic of Habermas to place all 
his hope in reason for overcoming his deepest cultural dread, distorted communication? Is Levinas aware that a philosophy which recognizes reality that transcends being, cannot do so if it remains rational philosophy? For reason gives us access to no more than being. So can Levinas continue to speak philosophically' when he secks a linal vocabulary for relating c'thically' to another?

Do people like I.cvinas and llabernas want to rescue reason and philosophy as Rorty's cultural overseer once more by acknowledging that the tradition has been too narrow? But an issue that may then be overlooked is whether or not there is $a$ IIIm!t to what rational philosophy, a tradition speaking a last word of truth with unnersality, con accomplish. If a rational philosophy should properly have been expected to have done what some say it has neglected - deal with the 'other', for example - an accusation of neglect makes sense only if rational philosophy can rationally deal with the other and do justice to this concem. So if rational philosophy is unahle to deal with the other for some reason, a helpful approach to the ollier may have to come fiom elsewhere

To put the matter somewhat differently: the accusation of a neglectful rational philosophy is to the point if philosophy makes legitimate claims to dealing with totality, universality, or the encompassing. But if those clains are legitimately contested, if rational philosophy should not be perceived as competent to deal comprehensively with genuine totality, then we are in more difficult waters.

\section{Initial exploration of an approach}

An approach to reason and philosophy in continuity with the above might be to see them as uscful in a limited way, prompting the question: what might be the proper limits? Knowing such limits could help us assess a philosophical response to marginalization which would expect philosophy to be more inclusive. A move toward greater inclusion might, for example, appear to be more 'politically' correct. But if it would require rational philosophy to move beyond its own rational limits, the question remains: are we helped by taking steps too big for our boots?

To make space for 'others' not now included in fullblooded rational being, we might, instead of doing something philosophical in which rational philosophy goes beyond the bounds of reason, consider that there's life beyond philosophy. If something is other than the status it has in philosophy, this possibly reflects the fact that reality and life exceed the limits of philosophy. By dealing with this other insofar as it ean lit into philosophy we may always be leaving it 'out' as other, if indecd we can deal rotionally with what is other only as same, that is, with 'other' as 'orhermess': And such conld possibly be so, if by rational we mean being within the logical space of reasoms. For in that space we can do no 
more than conceptually generalize, by remaining subject to rules of logic. But no general conceptual grasp of 'other' can in any real sense 'embrace' an other. The really other remains outside of the order of concepts. In that case, to get access and do justice to what is other we may need channels that are 'other than' reason, science, and philosophy. Film, novel, poem, other experiences (trust of myth and of mystery), other voices (the poor, women) all may help us get at 'truth' (a space for them where they can enter into the light and throw off their cover of sameness) in different and much needed ways; others need to be put into a different light in order to be really seen.

If we were to explore the limits of reason, would we discover that it is limited to bringing to light general structures by uncovering them inside the logical space of reasons? Please note: I am talking about a truth-revealing task, a labour that 'brings to light'. But I am also talking limits: structural truth. The limit here is twofold: reason as our limited source of light, structure as one kind of truth. Is that the core of what in a long Western tradition people have meant by reason: containment of reality within the boundaries of conceptualization? And in that tradition, is conceptualization a grasping of real universal structures which all things objectively have in common by virtue of things being enclosed by these structures? Are the 'reasons' of which we speak when we say 'logical space of reasons' indeed grounding functions of propositional statements in which reality has been conceptualized in terms of conceptual sameness? If answers to these questions tend toward the affirmative, then philosophy's universality is a very limited universality. And then philosophy's universality would become provincial if it did not recognize these limits. Philosophy would then be an example of narrowmindedness in the very broadmindedness with which it decorates itself.

Suppose there were something to this. Then the very idea of reason being aware of its own limits would be reason conceptually grasping the order of reasoning from within that order. But would that not amount to a very limited awareness of its own limits? And if those limits were not recognized? Would Gadamer then be right to unmask that as an unreasonable prejudice against prejudice? Would Dooyeweerd indeed be right that, necessarily, rational self-reflection requires more of a self than being rational? Indeed, occasion for a New Critique (Dooyeweerd, 1953-1958). A Critique, moreover, which is appropriately initiated by an inquiry into the self which in philosophy is trying to be self-critical.

If we stay with this for a moment we may entertain the idea that there is no need at this point to simply reject reason and philosophy. There might, after all, be a rational/ logical angle to any and everything whatsoever, so that even an appropriately limited reason might be able to present us with an analysis of all things, including an analysis of analysis, as well as an analysis of the other, the different, the transcendent. But that analysis would then be limited to otherness, difference, 
transcendence. Analysis would be a bringing to light of hidden structural moments of all things. That is, it would be limited to a conceptual analysis, an analysis of the concept of other, different, transcendent. And the concept would (in the case of a theoretical concept) be a grasping of implicit but uncovered structure, of a structural moment shared by things. It would be an analysis of difference, for example, as a same, as the difference we recognize all differences to be. But such an analysis of an other or of the other would never amount to doing justice to an other, embracing the other. Hence no more justice is being done to the other by creating more rational room for otherness in philosophy. And if it were mistakenly thought that more justice was being done, that could possibly result in more injustice continuing to be done.

If this is fruitful, we need to face the question: could conceiving rightly be conceived as a comprehending? Could a concept be comprehensive in the sense of encompassing, total? That now becomes highly unlikely. And Kant's (and Dooyeweerd's) way out, namely that what transcends the concept is known as idea, is not a genuine way out, for their idea remains a rational way of knowing and the rational limits thus remain. If analysis is not com-prehension, if it only prehends a moment of things, it is not everything, in spite of its legitimate angle on everything. So it could not accomplish what we could achieve with approaches to reality that lie beyond reason, approaches that are other and different: trust, love, feeling, poetry, music, and so much more. Rational analysis could not, then, deliver what these other approaches could deliver in relation to the other, the transcendent, mystery, authority, the subjective, the individual, and so many more. Reason's light and their light would differ.

The meaning of reason I here explore is, of course, writ large in science. Reason which logically explores concepts of structure is the theoretical reason of Aristotle and Kant, a professional rational operator in the logical space of reasons. Science seeks through reason to grasp a continuous same, a constant configuration of properties common to all things of some kind, for purposes of control. Lakoff (1987) has shown that this conceptualised same is at best an idealized same. But concepts are helpful. Concepts of order allow us to explain and predict and thereby increase our control. Reason operates outside of science as well and not all concepts are scientific concepts. But reason in science is prototypically reason.

Parenthetically: I know that by rational or reasonable, people (philosophers too) can and do mean more than what is confined to the logical space of reasons. But as soon as we do that, rational is no more than a metaphor for general approval, un unbounded term of admiration, projected from our veneration of what happens within the logical space of reasons to any domain beyond that space in which humans operate. Rational then means the same as sensible, sane, right, appropriate, 
meaningful, normative, and so on. But in that case rational philosophy loses any specific meaning. It means: good philosophy, without specifically showing why it is good. But if rational philosophy means: body of claims and accounts forned within the logical space of reasons, concerning the most general structure of things in general and thought to be uniquely correct, therefore having universal appeal; then we have a specific meaning of rational which also may be its most likely meaning with some continuity in the entire Western philosophical tradition.

\section{Rational philosophy}

I will now try to develop a fuller picture of what might fairly be called rational philosophy, a body of claims formed within the logical space of reasons. Within that space our basic elements are concepts. They are elements within a larger whole, a theoretical model, of which they are parts. Concepts of rational theory are mostly attempts at grasping, explicating, and bringing to the surface shared structures, developed primarily as instruments of control. Concepts are structural moments of reality, formed by using control as a cognitive model (Lakoff, 1987). They are often successful, beneficial, helpful instruments of control. That is a lot. But it is not all there is to reality. Within our controlled conceptual grasp we know but a side of things

In this context we can see the task of rational philosophy as the construction of an idealized model or framework for all special disciplinary conceptual models, a model that will allow us to bring coherence into our theoretical-conceptual world, as well as to conceptualize the relation of our theories to the greater body of concepts in everyday life. To use Quinean language: philosophy in this account organises the web of scientific beliefs and relates it to wider webs.

The idea that reality is itself given as structured the way philosophy sees it and has that structure for all times, combined with the idea that philosophy is our authority on truth whereby we order our lives, allowed the West to see philosophy as giving us what Rorty has called a 'permanent neutral framework' of truth. This framework gave reason in philosophy the illusion of being cultural overseer. However, work done in this context by Rorty and others has made a strong case for concepts neither being given nor forever. We make them and change them and they are not inclusive. The latter especially is one of the rich rewards of George Lakoff's empirical linguistic research (Lakoff, 1987).

Nevertheless, conceptual frameworks are or can be objective and can or do work for us reliably. Although they are 'made and not found,' they are at the same time not 'made up'. Good categories and concepts require careful analysis and solid empirical evidence. Objective concepts, though rationally and thus limitedly conceived by rational and thus limited people, are not a form of arbitrary inter- 
ference in reality, partly because of reality's resistance to such interference, partly because of respect shown to reality by concept makers.

Things in this world are 'there' independently from us. Conceptualizing them or categorizing them in earnest is real and important work. Though many things may not in principle be immune to distortive interference, we also are under severe constraints to avoid such distortion. If we have a concept of sweets that allows us to eat them carelessly, our teeth or our girth will inform us of our carelessness. That is: reality is 'corrective' of subjective distortion, even though the ozone layer tells us that sometimes we can go very long without seeing that we are distorting. The 'other' that is beyond the sameness of our conceived order in its very otherness has its own ways of preserving 'objectivity'. But that objectivity can then not, of course, be one of being 'cast out there', or objectified outside of us by reason. Rather, 'objective' will then need to characterize a relationship of mutuality in which the other is respected as other, and thus as an other whose reality transcends its conceptualization.

Conceptual frameworks largely help us order, structure, or make sense of our experience, our world. When scientifically developed, they also allow us to increase our control in the good sense of the word. And to repeat: other and different are not even completely beyond the sameness of conception, though they are conceptualized only as otherness, the other and the different, that is, as sames. Though that is reductive, it need not be wrong, so long as we do not consider conceptualization as being comprehensive and remember that to do other kinds of justice to reality we must sing, trust, paint, make love. The limits of philosophy or reason thus conceived cannot be overcome philosophically or rationally. They can at bes! be observed that way, and then only from a position inside the limits.

On this conception of reason as hunan rationality, reason brings us within the logical space of reasons and for anything to be rational is for it to go through the appropriate channels within that space. And for a philosophy to lay claim to being a rational philosophy, it would on this conception have to be the philosophy which even Rorty recommends, a look in general at things in general within the space of reasons. This kind of philosophy, that is, this construction of a wide theoretical framework which would be a home for our more partial theoretical frameworks such as those of physics, or biology, or sociology, or ethics, would be very useful and would contribute considerably to our ability to order our lives.

But there is another view of philosophy, the view that is oriented more to reason as practical reason, now emphatically understood as not theoretical, that is, not as reason proceeding within the logical space of reasons to provide a more general conceptual framework of things in general. Kant may have brought out the differences most starkly: the issues of practical life that have to do with ultimate ques- 
tions do not yield to empirical conceptualization within the logical space of reasons. They cannot be dealt with adequately within the enclosure. They yield antinomial incoherencies. But then does not the rational self looking for true guidance in the big issues of life look in the wrong place if he wants to be primarily rational in so doing? Does he not arrogate to reason tasks and functions best left to human capacities other than reason? Reason cannot do everything. It misses much in its intellectual grasp and is far from comprehensive.

To think that reason is capable of being cultural overseer and spiritual guide is likely a misinterpretation of what may in itself in certain respects be quite correct. If there is only one world and only one 'same in all', then if it is thought that only one true theoretical concept of anything's structure can be correct and if that concept is (mis)taken as a copy or representation of the real thing out there, then conceptual truth can be (mis)taken as 'correspondence' to the 'real'. It will be mis-taken if it is forgotten that the $o b$-ject originated as a pro-ject. In that interpretation rational truth 'presents' to thought, presents all over again within the mind, what it takes to exist objectively outside the mind. This picture is then interpreted as essential reality, the encompassing order. If reason takes that mistaking even farther, it may also drive us to say - as our culture has said - that we should not trust anything but reason if we want to know the truth about reality. But now reason has been accorded religious trust and its practitioners differ in no way from the priests of organised religion: they dispense myths. One of these myths will be that if we trust reason, reason does not need trust. Logically, within the space of reasons, this makes no sense of course. But it is not meant as a logic of reasons, but rather as a reassurance of trust. It is an antinomial or selfreferential incoherence only if looked at from within the logical space of reasons. As the confession of what a tradition ultimately trusts, it makes sense even to a reason-trusting rational self.

Reason that disqualifies trust hides the fact that such dis-trust is made possible on the basis of trust-in-reason. Trust in reason thus masks the trust it takes to deny our need for trust to know the truth. But in searching for the guidance we need in the big issues of human life: who we are, what we will become, what our origin and destiny are, the eschatological issues, we cannot depend on an isolated and autonomous reason, because the distance we are away from the realities we contemplate in these issues makes rational conceptualization inadequate at best. Here we are lost unless we trust the stories of trust, the myths that human communities have told us about their journeys through history. Such stories are not rational theories. They take the form of myths, poems, or songs because in these forms we can express what in the logical space of reasons becomes incoherent. In a tradition in which reason has the last word, every story of ultimacy, precisely because it is a story and not a theory, will be seen as containing strong rational incoherencies. This is amply demonstrated today by many who have trusted the 
story of reason, have duly noted that if tumed on itself it reveals self-referential incoherencies, and continue to expect the last word on this issue from reason.

Kai Nielsen's repeated clain, in virtually all of his many writings in philosophy of religion, that the concept of God in developed Judaism, Islan, or Cluristianity is (logically) incoherent is a fair claim. But it is not a fair accusation which puts its finger on something wrong. The word 'God', though requiring concepts for its meaning, does not simply refer to a single, colierent, rational-logical concept. Trust that reaches out to our intimations of reality at the limits of our experience allows itself to be expressed, but not to be abstractly and exclusively argued about logically. Reason's rejection of trust as a poor substitute for rational common sense is itself such an incoherent reality of the world of trust. For that rejection hides from the light of reason a covert call for trust in reason, which will never be revealed in the light of reason precisely because reason, while trusted, hides this from itself. In ultimately trusting reason as the last word, the rational self demands so-called rational pronouncenents on realities far beyond its reach. Reason may in sucl a situation in one and the same move deny the possibility that there are omnipotent beings and covertly act out in pseudo-omnipotence.

In a recent work Nielsen (1993:24) acknowledges that reason as a "necessary step on the historical road to universal enlightenment and human self-perfection" is a religious myth. And he rejects it. But he also insists that when truth is our overriding concern, reason should break ties with concens that conflict with it (Nielsen, 1993:12). Does reason provide the only ultimate clearing for things to come to light truly? Perhaps not entirely, for even more recently he has suggested a positive role for religion in the realm of what he calls "the existential functions of religion ..." (Nielsen, 1994:22). These, for Nielsen, pose questions that "standing where we stand now in cultural history, no thoughtful and informed person should think she has a good answer to" (Nielsen, 1994:35). And in that context he speaks about (rational) truth as possibly "outweighed by other considerations" (Nielsen, 1994:37).

\section{Focus on trust}

What is this trust I have mentioned? It is a channel of revelation of ultimate mystery. Life is full of mystery. It may take some courage for a rational self to admit this. But much of reality is covered over with a veil that is beyond rational penetration. That is mystery. Some of it can be revealed. Revealing is itself nothing unusual. For example, when we discover officials did not quite know how well prepared the subway trains were for a cold snap, they may excuse themselves by saying 'Only actual winter conditions will fully reveal the condition of our machines'. That is all there is to 'revealing'. Something that was in the dark canc to light. 
Trust (living-in-trust) reveals whatever truth is available of life's boundary mysteries: origin, destiny, salvation, suffering, evil, and so on. This requires trusting our lives with the narratives of a tradition. In these narratives the accumulated trust of certain intimations of life's mystery is deposited as guide for life. They clear a space in which light falls on some of the things otherwise veiled in mystery. In trust some of the covering comes off. Mystery is revealed in the vulnerable action space of trust, just as structure is conceptualized in the logical space of reasons. Truth of revealed mystery is aletheia: trust in what shows up in a clearing of vulnerability. 'Resurrection' may be a word inspiring us with hope as we live toward the boundary. A rational or scientific theory of 'resurrection' is nonsense. So is a concept of resurrection logically accessible to reason. But living a life oriented to trusting a resurrection narrative will reveal something, either truth or a lie.

For example, in capitalism the truth is for sale and the poor pay the price. In socialism the truth is belaboured till nobody can afford anything anymore. In both worlds the truth is revealed economically in the market. Neither the reason of capitalist multinationals nor the reason of socialist unions will bring to light the lie in today's market, for in both approaches to the world via the market, truth is revealed in the light of their trust. In the same way, in the philosophical tradition I have been thinking about, truth is not trusted if not coherently conceivable in the logical space of reasons.

It is possible to trust a tradition of reason as ultimate guide to wisdon and hope, and thus to have certain revelations. Reason then becomes trusted as the true source of all light and as the clearing in which all mystery comes to light. These revelations are rooted in trusted articulations of the trust in reason. They are the myths of the philosophical tradition of the rational self, such as the myths of rational foundations, of fornal languages of unified science, or of meaning and verification. Even if someone shows theoretically that such articulations are selfreferentially incoherent, they will survive so long as they are trusted. That is the whole point of their self-referential, in this case rational, incoherence. For these ultimates are impenetrable to reason. They are trusted and thereby, instead of having foundations in reason, become foundations for reason.

Only a life lived in trust can put such a trust to shame. Our Western life of trust in rational autonomy reveals to many that this trust is problematic. This trust is blind to itself being trust in rational authority. It seeks to defend itself against the accusations of marginalization by countercharging that a world not governed by reason is arbitrary and relativistic, individualistic and subjectivistic. It is intolerant to truth of trust, to truth of art, or of love, or of justice. 
I hope this brief focus on trust has revealed that reason in the West, far from having been encompassing and comprehensive, has had its deeper roots in trust and has encompassed itself with self-trust. I think this also reveals that trust goes deeper and reaches farther than reason ever can or will. But it does not mean that we can reject reason. It does not even mean that we cannot trust reason ever or at all.

\section{Back to reason and philosophy}

If the line of argument developed so far has merit, our approach to problems of rational autonomy could be one of limiting reason to doing what it can and should do: work within its own limits. This approach would not make reason or philosophy more inclusive, but would relativise it. And it would also relativise the order of reason, especially the order uncovered in the wake of search for control. Philosophy would be no more than the internal integration of the theoretical enterprise.

What about the other, the marginalized, the different? We who are more than rational as the selves that we are, we as living agents know as we reason that there is much more reality beyond reason; reality we as agents love, care for, sing about, trust, and many other things. The self as agent, even in being rational, is aware of transcendence, mystery, and the other, though not rationally so. 1 know more than I think. I also know at other times, for example when I love, trust, appreciate, feel, grow, care, sing, listen. All of these have their limits, as does rational understanding. We cannot see everything, yet know more than we see. We also cannot understand everything, yet know more than we understand. As agents we do all of these. And we can allow our reason to be open to other sides of our agency, including our ultimate trust.

Philosophy is a legitimate conceptual strategy for conceptual integration of our conceptual frameworks, theories, worldviews. It brings conceptual comprehension, coherence and integration to partial concepts and conceptual configurations. Conceptually the result is a general totality of structural sameness called order, traditionally constructed in the enterprise of ontology. But philosophy in this tradition is not guardian of truth, essence, reality, meaning, justice, the good, and mystery. Philosophy in this tradition is also not the enemy of relativism, irrationality, subjectivity, experience, individuality, the different. It cannot have the first/last word. II can, however, thoughtfully contemplate whatever we live by in trust. Thought about a reality revealing itself to trust, governed by trust's own peculiarities not subject to reason, is legitimate. But it will have to observe its limits. What is trusted and what we articulate about our trust does not fit within the logical bounds of reason. Trusted omnipotence as well as trusted rational justification of reason become incoherent within the logical space of reasons. The 
mythical language of trust, ultimacy, and revelation in the face of mystery can be known only in being trusted and it is truly trusted only in actively guiding a life lived in this trust.

\section{Conclusion}

If indeed the rise of philosophy in ancient Greece was from the beginning connected with the replacement of the tradition of religious faith (in which faith was known as a life of trust and not - though beliefs were an aspect of faith - a cognitive body of beliefs), then it is understandable that the rational-noctic view, picture, image, copy of reality had the religious function of capturing the truth about reality construed as a God's-eye-view. Now that after two millennia we are questioning this development because of its distorting and oppressive consequences, two major approaches emerge as possibilities of dealing with this Western inheritance. One would be to acknowledge the limited, relative, and legitimate merits of a very broad conceptual framework to help integrate more partial conceptual frameworks and thereby contribute to elements of colierent ordering and wholesome control which are a necessary dimension of human culture. This toned down version of rational philosophy would then not give us privileged access to truth, would not be the privileged source of an immutable and essential order which encompassingly encloses all of reality, and could not be made more serviceable by assigning it tasks which transcend the limits of reason but whose outcomes are nevertheless presented as rational. In this approach reason and philosophy need to acknowledge faith, religion, and spirituality as normal and legitimate dimensions of human existence, different from, but not competitors of reason, contributing to human experience in their own way.

The other approach would be to continue to regard reason and philosophy as the last word on truth, as supreme guide in life and culture, as our most reliable orientation in issues of origin and destiny. But then this should be acknowledged as religious trust in reason and philosophy, where there is no rational justification for granting this place to reason, but only hope. This is the religion of reason, Jaspers' philosophical faith, which can demand no superiority to other religions except on the only ground we have to decide issues of ultimacy, namely whether the life of trust in reason delivers human happiness and wellbeing, leads to a flourishing of human culture, saves us from oppression, distortion, and suffering more than a life of faith in God. Choice here is; largely, a matter of trust.

\section{Postscript}

I began this piece with a preface and must end it with a postscript. My explorations between preface and postscript were occasioned by reflections on a theme discussed by Stoker and Dooyeweerd and were intended to honour Stoker. But 
the explorations have revealed something I already referred to in the preface: if you limit your concern for the other to a philosophical concen for otherness, you run the risk of doing injustice to the other. And Stoker's philosophy, in spite of his concern for the other, lent comfort to the architects of apartheid. Not surprisingly, for apartheid may with some justification be called an intellectual consiruct whose builders were unaware of the pain caused by the concepts they so admired. It worked only within the brain, never in the land. So how do I honout a philosopher whose philosophy is linked to that pain?

Ilaving written the paper I wrote, this question is unavoidable. If the voice of the other camnot be heard $a s$ other in philosophy, philosophy and the other are doomed. And in this volume of intellectuals honouring an intellectual, the 'others' in this context must be allowed to be present. I owe them a response as to why $I$ honour Stoker, when I demonstrate in my piece that his though kept them apart from a system which aimed to include them.

And this is where I hope the postscript connects with the preface. Stoker's concem with alterity as a philosophical concen contributed to injustice. But I trust that the concern originated in 'the other Stoker'. This genuinely pious, humble, open child of the Other and friend of others was undonbtedly inspired in his philosophical concern for alterity by his deep respect for the limits of reason. It put him in touch with all that transcends reason, above all with the Transcendent. In his philosophical concen, if we regard it as a 'posmodern' intuition that did not fully blossom, we may see how Stoker heard the Other pass by (as Levinas might put it) or how he preserved a trace of the ofher (as Derrida might put it).

Being an intellectual is a dangerous business, as the history of reason in the West shows. If intellectuals honouring an intellectual would remain shut off in their intellectual world, occasions like this volume could thereby alone become offensive. So I have tried in this essay to open intellectual windows to real dangers. And I took up this theme because my present disconfort in my own reformational tradition with the remainders of the autonony of reason was in part started by Stoker. His plea for alterity in philosophy in discussions with Dooyewcerd in the sixties, in which I participated, kindled my discomfort within me. For that reason I gratefully honour him, but for that same reason I also needed to explore this theme in 'other' directions.

The philosophical calegories of Stoker's time tended often not to be informed by the lamenting voice of distorted human relations, especially if the lament came from others. The cry of such a voice was likely silenced because it always transcends our concepts. Nevertheless, there was the still, small voice of the 'idion,' a voice within his thought. Today that voice has more space in which to resound, to be echoed. Honouring Stoker in postmodern and rapidly coming post-apartheid society could take the form of hearing the voice of the idion, and Irusting it. 


\section{Bibliography}

NB. There are no entries in this bibliography for general references to widcly known work of wellknown philosophers, even when a specific plrase is used, such as Descartes' 'Cogito, ergo sum'.

BRÜGGEMANN-KRUYFF, Athie, Th. 1993. Bij de Gratie van de Transcendentie: In gesprek met Levinas over het vrouwelijke. Amsterdam : VU Uitgeverij

CODE, Lorraine. 1991. What Can She Know? Ithaca : Corncll University Press.

DOOYEWEERD, Herman. 1953-1958. A New Critique of Theoretical Thought. Amsterdam and Philadelphia: H.J. Paris and The Presbyterian and Reformed Publishing Company. 4 Vols.

LAKOFF, George. 1987. Women, Fire, and Dangerous Things: What Categories Reveal about the Mind. Chicago : University of Chicago Press.

LLOYD, Genevieve. 1984. The Man of Reason: "Male" and "Female" in Western Philosophy. Minneapolis : University of Minnesota Press.

NIELSEN, Kai. 1993. Atheism without Anger or Tears. Unpublished typescript.

NIELSEN, Kai. 1994. Is Religion the Opium of the People? Marxism and Religion. Unpublished typescript.

NYE, Andrea. 1990. Words of Power: A Feminist Reading of the History of Logic. New York: Routledge.

SCHOULS, Peter. 1980. The Imposition of Method: A Study of Descartes and Locke. Oxford : Clarendon Press.

STOKER, H.G. 1970. Oorsprong en rigting. Kaapstad : Tafelberg. 2 Vols. 